\title{
AN EXPLORATION OF THE TERM UNDERCLASS AS IT RELATES TO AFRICAN-AMERICANS
}

\author{
GARRY L. ROLISON \\ University of Oklahoma
}

Lately, a new concept has entered the sociological and popular lexicon to describe the class position of the urban Black poor. That concept is underclass. Unfortunately, this concept has been mired in terminological difficulty and theoretical imprecision. This article is an attempt to remedy both of these shortcomings.

The term underclass has at least four distinct theoretical meanings in the contemporary literature. The first, and most relevant for the purposes of this discourse, defines the underclass as those who have no stable relationship to the labor market (Giddens, 1973; Myrdal, 1963; Wilson, 1980). The second defines the underclass in descriptive terms as simply that stratum at the bottom of the stratification order (Billingsley, 1968; Cottingham, 1982). The third defines the underclass as consisting of those individuals who stand outside of the normative structure of society (Auletta, 1982). And fourth, Marxist scholars fuse the previous definitions and define the underclass as those who have only a marginal relationship to the labor market and who suffer extreme poverty (Boston, 1984; Darity, 1982; Marable, 1983; Szymanski, 1983).

While there is a certain ambiguity with regards to the theoretical precision of the concept underclass, there is striking popular con-

\footnotetext{
AUTHOR'S NOTE: The author wishes to thank Douglas H. Daniels, Roger Fricdland, and Cedric Robinson for their comments on an earlier draft of this article.
} 
sensus with respect to the characteristics that differentiate it from others in U.S. society. First, they are unemployed or underemployed. Second, they are predominately Black. Third, they are essentially an urban population. Finally, and most importantly, they lack prospects for social mobility. In other words, regardless of the way in which the underclass is defined theoretically, it is popularly understood as being socially immobile, unemployed, urban, and Black. It is helpful to keep in mind this definition of the underclass because of the explicit links between it and previous discussions of urban Black poverty.

\section{A BRIEF REVIEW OF PERSPECTIVES ON BLACK POVERTY}

Beginning with Michael Harrington's (1962) book, The Other America, social scientists and the American public rediscovered poverty. Later analysts were to concentrate on the connection between poverty and race in urban centers (Sackrey, 1973). From these latter efforts, two major perspectives took shape.

The first perspective saw the continued low socioeconomic status of a disproportionate number of Blacks in cities as the result of past and present racial discrimination. The second argued that poor urban Blacks were somehow responsible for their condition because of cultural handicaps. Generally, these two perspectives could be distinguished on the basis of whether economic and social structural relationships were emphasized or whether cultural and normative systems were. In one perspective, Black urban poverty was attributed to "institutional racism," in the other, to a "culture of poverty" (Gotsch-Thomson, 1984).

The first perspective is probably most developed in the internal colonial model of racial oppression as exemplified in the works of Kenneth Clark (1965), Carmichael and Hamilton (1967), and later in the writings of Allen (1970) and Blauner (1972). In this model, Blacks are trapped in a ghetto that is controlled administratively, politically, and economically by White elites who benefit from its maintenance. In toto, this process of colonialization is posited to 
maintain and reproduce a permanent stratum of Black poor in large U.S. urban centers.

Culture occupies a central role in the writings associated with the second perspective. However, instead of stressing putative cultural domination as internal colonial theorists are wont to do, this perspective focuses on putative cultural defects within the Black community. The writings of Banfield best typify this perspective. In particular, Banfield (1974) argued that a disproportionate number of urban Blacks are poor because a disproportionate number are members of a "lower-class" whose style of life, beliefs, and values place them at a disadvantage for full participation in the social and economic mainstream. Moreover, Banfield posited that these traits are transmitted intergenerationally, so that a Black lower class becomes a permanent feature of the urban landscape. ${ }^{2}$

In sum, the fact that most contemporary analysts agree that the underclass is urban, poor, and Black suggests direct lineage with earlier perspectives on Black urban poverty in the United States. Given this, it is reasonable to ask why the new concept underclass has increasingly come into the sociological literature and what, if any, conceptual clarity it adds to our understanding of the Black urban condition. In particular, how does the Black underclass differ from the Black urban poor? What precisely is the sociological content of the concept? To answer these questions, I look first at the sociological genesis of the concept and then offer a reconceptualization.

\section{WHY NOW AN UNDERCLASS?}

The first sustained usage of the term underclass appeared in Myrdal's (1963) work, A Challenge to Affluence. In that work, Myrdal defined the underclass as

(the) unemployed and, gradually unemployable and underemployed persons and families at the bottom of a society, while for the majority of people above that layer the increasingly democratic structure of the educational system creates ever more real liberty and equality of opportunity over the course of two generations. (p. 34) 
There is much in Myrdal's definition. Of particular note, however, is the emphasis it places upon the centrality of underemployment and social immobility, reflecting changing structural factors within the economic and political system, as prompting the underclass. This is central to contemporary definitions of the underclass: the recognition that there now exists among the U.S. poor a group that is permanently or irregularly unemployed and underemployed and who, in contrast to the poor, lack the possibility for inter- or intragenerational social mobility.

As Glasgow (1981, pp. 3-4) pointed out, Myrdal's formulation was not well-received. Such a thesis is contrary to the American myth of unlimited social mobility. More troublesome was the vision that this growing underclass was to be engendered by the same structural changes in the U.S. polity and economy that would proffer increased social affluence to other segments of society. In short, Myrdal (1963) offered a vision of the United States in which the growth of "large-scale, organized, and stratified industry that increased the need for educational training" would also result in reduced need for unskilled labor and an increasing pool of redundant, unemployed, and unemployable persons "who have happened to be born in regions, localities, or economic and social strata where education and training for life and work in this new America are not provided as a normal thing" (pp. 37-38).

\section{SOCIOLOGICAL ROOTS: MARX, WEBER, AND GIDDENS ON THE UNDERCLASS}

Myrdal's observations on the underclass were long anticipated by Marx. As Darity (1982) pointed out, Marx defined the stagnant layer of the relative surplus population as that "part of the active labor army, with extremely irregular employment" (Marx, 1867/ 1967, p. 643); and like Myrdal, Marx agreed that this fractional class is the result of advancing capitalism and that "it recruits itself constantly from the supernumerary forces of modern industry and agriculture, and specially from those decaying branches of industry where handicraft is yielding to manufacture, manufacture to ma- 
chinery" (Marx, 1867/1967, p. 643). ${ }^{3}$ Weber (1978), too, was wellaware of the unfavorable impact of the uneven advance of capitalism on the lowest echelon of the proletariat, so much so that he chose to define those who were in a "uniform class situation" as being "completely unskilled and propertyless ... (and) dependent on irregular employment" (p. 302). Contemporary class analysts have almost wholly continued to view the underclass in this tradition, with one notable exception.

In Giddens's (1973) work, The Class Structure of the Advanced Societies, the underclass is defined as "a status group where ethnic differences serve as disqualifying market capacity, such that those in the category in question are heavily concentrated in the lowestpaid occupations, or are chronically unemployed or semi-employed" (p. 112). Although this definition of the underclass is strikingly similar to Marx's, Weber's, and Myrdal's definitions of underclasslike groups, it differs in that it posits ethnicity as the allocative mechanism of underclass membership and ethnic struggle as a major determinant of underclass formation.

To fully grasp the significance of Giddens's formulation of the underclass, it is important to note how Giddens arrived at his conceptualization of the underclass. Giddens (1973) carefully separated Weber's original concept of status group into its constituent parts of social esteem and common patterns of consumption and asserted that the latter

are significant to the degree that they reinforce the typical separations between forms of market capacity .... The most significant distributive groupings ... are those formed through the tendency towards community or neighborhood segregation. (p. 109)

In short, Giddens's work is of basic importance because, unlike work that precedes or follows, it recognizes ethnic struggle as a mechanism of labor-market exclusion that is itself an integral part of underclass formation. In essence, Giddens's insight was to tie the Marxist trinity of production, distribution, and exchange in advanced capitalist nation-states, as they interact with ethnicity, to the formation of the underclass. It is my intent to add further clarity. 
There are problems with the above conceptualization of the underclass, however. First, is the underclass a fractional portion of the proletariat or a class in its own right? Second, is it ethnicity or racial membership that is of salience with respect to the allocative mechanism of underclass formation? The first question points to the problem of how to actually define class: Are classes creatures of production, distribution, exchange, or a combination of all three? The second question speaks to whether race and ethnicity really have the same social content as stratifying mechanisms. While at this point I turn to the first of these questions, it should be clear that in this brief article, I can only answer in broad brush what are intrinsically thorny issues. Nevertheless, it is hoped that some understanding can be gained vis-à-vis these larger issues from even this cursory exploration.

\section{A THEORETICAL DERIVATION OF THE UNDERCLASS FROM MARXIST AND WEBERIAN CLASS CATEGORIES}

Ossowski (1963) has pointed out that there are three dominant conceptions of class in sociological literature. The first stems from Marx and defines class in relational terms (Wright, 1979). That is, classes are defined relative to a given aspect of the social structure (whether they own the means of production, whether they exercise power) and relative to each other (a class exists only insofar as another class is antagonistic to it). Wright $(1979$, p. 5) termed the second use of class, as attributed to Ossowski, gradational. That is, classes are defined and stratified by the quantity of valued social goods vis-à-vis other classes. Finally, as Giddens (1973) pointed out, Ossowski also suggested a functionalist conception of class, where a multiplicity of classes are "divided into functionally interrelated groupings in the division of labor" (p. 65). It may be suggested that Ossowski's conceptualizations of class follow rather neatly the tripartite division of the economy into the spheres of production, distribution, and exchange.

It is here that Weber's discussion of class is most helpful. This is because of Weber's explicit attempt to conjoin all three economic 
spheres in his elucidation of economic class. That is, while Weber followed Marx in asserting that the property/propertyless distinction is the major axis by which to determine class position, he extended this division beyond the sphere of production and into the spheres of exchange and distribution. As a result, for Weber the struggle between the owners of the means of production and the sellers of labor power was only one struggle that can properly lay claim to the title of class struggle. Such struggle also occurs between the rich and poor and the skilled and nonskilled. Hence, for Weber uniform class position, that totally degraded condition Marx took as the eventual fate of all the proletariat, could only refer to a subgroup of the proletariat at any given point in time. That is, to those who did not own the means of production, who were poor, and who had no skills to exchange in the market. In other words, it is here that the underclass, at least in strictly economic terms, is located and emerges as a class that is structured from class struggle in all three spheres of economic activity. Because of this, both the proletariat and bourgeoisie are dominant classes to the underclass, and political struggles involving the transfer of wealth or the usurpation of skills mark the respective class struggles between these dominant classes and the underclass.

Clearly this is a revision of orthodox Marxist class theory. Paradoxically, however, it is a revision that is consistent with the relational logic of Marxist class analysis. In essence, if the underclass is truly a class, then using the relational/objective class framework inspired by orthodox Marxism, it must logically be a class that is objectively subordinate to the proletariat and exists in antagonistic relationship to the proletariat. On all counts, the underclass as I have defined it fits. The shift occurs because of the Weberian inclusion of the sphere of exchange as a site of class formation and struggle.

This is more than simple conceptual juggling. It speaks to a central problem with the relational conception of orthodox Marxist class categories as they are solely derived from the sphere of production (Parkin, 1979). For various reasons, this has proven unsatisfactory. Specifically, the relational notion of class, especially as associated with orthodox Marxism, is always beset with the 
Ownership Means of Production

\begin{tabular}{|c|c|c|c|}
\hline & & Yes & No \\
\hline \multirow[t]{2}{*}{ Seller of Labor-Power } & No & Bourgeoisie & Underclass \\
\hline & Yes & $\begin{array}{c}\text { Petite } \\
\text { Bourgeoisie }\end{array}$ & Proletariat \\
\hline
\end{tabular}

Figure 1: Class Typology.

problem of intermediate classes between the proletariat and the bourgeoisie (Parkin, 1979, chap. 2). By defining the underclass in the way I have, I also suggest that orthodox Marxian class analysis is plagued by the problem of excluding classes not technically within salient class relations (i.e. the commodified labor form) yet ultimately determined by those relations.

To be less abstract, since Marx defined classes in capitalist society on the dual bases of whether they own the means of production and whether they must sell their labor power (market exchange), four classes are logically indicated. Yet, Marx defined only three - the bourgeoisie, the proletariat, and the petty bourgeoisie. As the matrix below indicates, Marx failed to identify that class which neither owns the means of production nor is able to sell its labor power. In short, Marx left the underclass, as I have defined it, untheorized.

This failure has profound theoretical implications because it makes impossible a grounded notion of antagonism between the proletariat and the underclass, such as that mentioned above. ${ }^{4}$ In short, and to follow Parkin (1979), orthodox Marxism is unable to discover that while the proletariat seeks to "usurp" the ownership of the means of production from the bourgeoisie, it also attempts to "exclude" the selling of labor power by another propertyless class through social closure. This process, following Weber (1978, p. 342), 
typically manifests itself in the sphere of exchange and takes the form of closing economic opportunity to "outsiders." It is this process of exclusion that creates the underclass and the proletariat as mirror images within the sphere of exchange and ensures that the material interests of the two classes will be contradictory.

To sum up, the underclass can be seen as existing within two relations of domination. The relation of domination that it shares with the proletariat, which forces the class to be propertyless and therefore reliant upon selling its labor power, and the relation of domination that prevents the free exchange of its labor power within the market via the process of social closure. ${ }^{5}$

With respect to this latter relation of domination, it is to be noted that while it ensues in the sphere of exchange, it takes as the basis of exclusion the "most easily seized upon" status-group difference (Weber, 1978, p. 342). In short, if we follow Weber's lead, this type of market class struggle uses as its principle of exclusion the most visible products of the sphere of distribution - status groups. Here we return full circle to Giddens's (1973) formulation of the underclass and to the second question that began this section. Namely, the problem of whether race or ethnicity is more salient in underclass formation. It is to this that I now turn.

\section{RACE AND UNDERCLASS FORMATION}

If ethnic and racial group stratification both represent the same social process, as many scholars suggest (e.g. Bonacich, 1976), then it may be the case that racial and ethnic groups can be differentiated by the common factor that informs this process. That common factor, it is typically argued, is unequal power relations (see Noel, 1968; Stone, 1985). I would like to suggest that we can best discern the relative power differential between ethnic and racial groups by the power they have in defining themselves and in resisting the social definitions of others. ${ }^{6}$ In short, I would like to suggest that ethnic and racial group stratification can be differentiated as social categories on the basis of whether racial and ethnic identities are 
either self-generated or other-imposed. I explore the basis for this below.

To understand the above, it is first necessary to accept the assumption that social groups define themselves in relation to other social groups primarily upon the uniqueness of the differences of their life-styles and that this involves a measure of ethnocentrism. In short, I argue that these two factors in tandem create ethnicity. Indeed, given our two assumptions, all that is needed for ethnicity to occur is simple contact between dissimilar cultural groups who evidence some measure of ethnocentrism. What is of importance here is that unequal power between groups is not necessary to the construction of ethnicities. In contrast, I would like to suggest that unequal power relations is the "stuff" needed to construct racial identity. That is, I propose that racial identity in contrast to ethnic identity can only emerge within a context of domination.

The reason for this latter proposition is two-fold. First, initial contact between groups of unequal power determines in large measure the degree to which one group is capable of imposing its social identity upon another group and of later having that definition come to be accepted over the subordinate group's previous selfidentity or ethnicity. That is to say, the process of racial identity formation becomes possible only when the dominant group is able to displace the subordinate group's previous ethnic self-identity and impose in its place the single criteria of visible physical difference, as the dominant group constructs it (see Blauner, 1972; Memmi, 1967). Moreover, once initiated, this racial identity can only be maintained when the dominant racial group affixes intergenerational immutability to these socially constructed physical differences. In the absence of such immutability, the social category of race, and hence the social domination that it represents, is eliminated. Hence, unlike ethnic domination, where assimilatory efforts by the dominated group can simultaneously eradicate ethnic identity and therefore modify an existing system of ethnic stratification, a system of racial domination remains relatively fixed because the eradication of racial identity is for the most part outside of the scope of the dominated group's amalgamatory efforts. That is, whereas a sub- 
ordinate ethnic group can through the process of assimilation typically attain dominant-group membership, the subordinate $r a$ cial group through amalgamation typically cannot. ${ }^{7}$

The above discussion is particularly germane to the question of the relative saliency of ethnic and racial membership in the process of social closure and hence the acquisition or nonacquisition of property within the sphere of exchange which then comes to determine underclass membership in advanced capitalist societies. In short, to the degree that racial membership, in contrast to ethnic membership, contains a degree of immutability (see van den Berghe, 1967), then it more than ethnic membership can serve as the external characteristic needed for social closure and therefore property exclusion in the labor market. In short, racial membership becomes the mode of structuration for underclass formation.

Having said the above, it is important to state that these constructs of racial and ethnic identity are endpoints on a continuum that reflects the relative power of groups to have their self-definitions accepted or replaced by a dominant racial/ethnic group(s) and the relative mutability of that status in a given social order through acculturation and amalgamation, respectively. Therefore, there is a certain fluidity between racial and ethnic identity, as well as the possibility that either may be used as a device of exclusion from property acquisition. What is of importance to our discussion is that, in societies in which race has been socially constructed, racial membership will most likely serve as the axis along which property exclusion occurs and therefore as the exclusionary device needed for underclass formation.

From the preceding discussion, we can then define as an underclass that subgroup of the propertyless engaged in capitalist social relations who are denied the exchange of their labor power as an interactive function of their subordinate class position and racial membership. As a result, members of the underclass are simultaneously underemployed and tend to belong to a disprivileged racial group. Such a conceptualization of the underclass on the one hand seeks to unify the economic structuring of the class as a product of class antagonisms in the respective spheres of production, exchange, 
Intergenerational Immutability

\begin{tabular}{|c|c|c|c|}
\hline \multirow{3}{*}{ Self-Defined } & & Yes & No \\
\hline & No & $\begin{array}{l}\text { Racial Group } \\
\text { (e.g. Black } \\
\text { Americans) }\end{array}$ & $\begin{array}{l}\text { Racial/Ethnic } \\
\text { Group (e.g. } \\
\text { Chicanos) }\end{array}$ \\
\hline & Yes & $\begin{array}{l}\text { Ethnic/Racial } \\
\text { Group (e.g. } \\
\text { Chinese- } \\
\text { Americans) }\end{array}$ & $\begin{array}{l}\text { Ethnic Group } \\
\text { (e.g. Irish- } \\
\text { Americans) }\end{array}$ \\
\hline
\end{tabular}

Figure 2: Racial/Ethnic Typology.

and distribution and on the other, to locate racial membership as the prime mode of structuration (see Giddens, 1973, p. 105).

\section{DISCUSSION}

The definition of the underclass offered above differs substantially from definitions employed by other analysts. As mentioned earlier, much contemporary discussion of the underclass defines it simply in terms of poverty. This is unfortunate; while poverty is a concomitant condition of the underclass, it alone does not define it. The underclass is a class and not a stratum. To iterate, the underclass is defined by its lack of opportunity for stable inclusion into the labor market due primarily to its interests that are antagonistic to the proletariat in the sphere of exchange.

Moreover, simply defining the underclass in terms of poverty is problematic, as it underplays the crucial import of race as the mode of underclass structuration in a racialist society. In short, it should be understood that the Black underclass differs fundamentally from the White poor because of its exclusion from the labor market as a result of the cultural construction of racial membership as an axis of social closure in a multiethnic, multiracial society such as the United States. In other words, by not paying sufficient attention to 
the enduring quality of racism and its class basis and function, many analysts have confused the poor - those with little income but with the possibility for either intra- or intergenerational social mobility - with the underclass - those who are without such possibilities due primarily to a racial status that prevents the full and equal exchange of their labor power in the market.

\section{NOTES}

1. For recent examples of this popular conception of the U.S. underclass see, "America's Underclass: Broken Lives," U.S. News and World Report, March 17, 1986, and "The Origins of the Underclass," The Atlantic, June/July 1986.

2. Although Banfield's writings were most influential in the late 1960 s and early 1970 s, this culturalistic interpretation of urban Black poverty has continued in some variants of dual labor-market theory (e.g. Piore, 1971), as well as in its pure form by analysts such as Gilder (1981), Kilson (1981) and Sowell (1975), among others.

3. It is to be noted that Marx's definition of manufacture differs substantially from the contemporary definition. Indeed, Marx termed machinofacture what is contemporarily called manufacture. As a result, it is technically incorrect to equate Myrdal and Marx on this point. Nevertheless, it is clear that orthodox Marxism implies that as machines come to replace humans in the productive process, there is a tendential rise in relative unemployment.

4. Marx appeared to be vaguely aware of such an antagonism, as witnessed by his discussion of the lumpen-proletariat in "The Eighteenth Brumaire of Louis Bonaparte" and "The Class Struggles in France, 1848-1850." However, because of the moral tenor of his argument, Marx refused to theorize the lumpen-proletariat as having material interests that are contradictory to the material interests of the proletariat. He was thereby forced to see this class as an easily bribed reactionary ally of the bourgeoisie.

5. In short, the underclass is simultaneously engaged in class struggle against the bourgeoisie in the sphere of production and against the proletariat in the sphere of exchange.

6. Lieberson (1961) had made a similar point with regards to the dynamics of origin and maintenance of racial/ethnic groups in general.

7. The above discussion is heavily indebted to the previous theoretical efforts of Licberson (1961) and Wilson (1973), among others.

\section{REFERENCES}

Allen, R. (1970). Black awakening in capitalist America: An analytic history. Garden City, NY: Anchor.

Auletta, K. (1982). The underclass. New York: Vintage. 
Banfield, E. C. (1974). The unheavenly city revisited. Boston: Little, Brown.

Billingsley, A. (1968). Black families in White America. Englewood Cliffs, NJ: PrenticeHall.

Blauner, R. (1972). Racial oppression in America. New York: Harper \& Row.

Bonacich, E. (1976). Advanced capitalism and Black/White race relations in the United States: A split labor market interpretation. American Sociological Review, 41, 34-51.

Boston, T. D. (1984). Some preliminary notes on the question of Afro-American social classes: The Shanghai lectures. The Eighties, 4, 42-62.

Carmichael, S., \& Hamilton, C. V.(1967). Black power: The politics of liberation in America. New York: Vintage.

Clark, K. (1965). Dark ghetto. New York: Harper \& Row.

Cottingham, C. (1982). Race, poverty and the urban underclass. Lexington, MA: Heath.

Darity, W. A., Jr. (1982). Economists, the minimum wage, and the underclass. In C. Cottingham (Ed.), Race, poverty and the urban underclass. Lexington, MA: Heath.

Giddens, A. (1973). The class structure of the advanced societies. London: Hutchinson University Library.

Gilder, G. (1981). Wealth and poverty. New York: Basic Books.

Glasgow, D. G. (1981). The Black underclass. New York: Vintage.

Gotsch-Thomson, S. (1984). Correlates of poverty: An analysis of demographic, structural, and individual factors related to poverty in the Black-belt counties of Alabama. Review of Black Political Economy, 13, 61-80.

Harrington, M. (1962). The other America. New York: Penguin.

Kilson, M. (1981). Black social classes and intergenerational poverty. The Public Interest, 64, 58-78.

Lieberson, S. (1961). A societal theory of race and ethnic relations. American Sociological Review, 26, 902-910.

Marable, M. (1983). How capitalism underdeveloped Black America. Boston: South End Press.

Marx, K. (1967). Capital: Vol. 1. A critical analysis of capitalist production. New York: International Publishers. (Original work published in 1867)

Memmi, A. (1967). The colonizer and the colonized. Boston: Beacon.

Myrdal, G. (1963). A challenge to affluence. New York: Pantheon.

Noel, D. L. (1968). A theory of the origin of ethnic stratification. Journal of Social Problems, $16,157-172$.

O'Connor, J. (1973). The fiscal crisis of the state. New York: St. Martin's.

Ossowski, S. (1963). Class structure in the social consciousness. New York: The Free Press.

Parkin, F. (1979). Marxism and class theory: A bourgeois critique. New York: Columbia University Press.

Piore, M. J. (1971). The dual labor market: Theory and implications. In D. M. Gordon (Ed.), Problems in political economy: An urban perspective. Lexington, MA: Heath.

Sackrey, C. (1973). The political economy of urban poverty. New York: Norton.

Sowell, T. (1975). Race and economics. New York: McKay.

Stone, J. (1985). Racial conflict in contemporary society. Cambridge, MA: Harvard University Press.

Szymanski, A. (1983). Class structure: A critical perspective. New York: Praeger. van den Berghe, P. L. (1967). Race and racism: A comparative perspective. New York: Wiley. Weber, M. (1978). Economy and society: An outline of interpretive sociology. Berkeley: University of California Press. 
Wilson, W. J. (1980). The declining significance of race (2nd ed.). Chicago: University of Chicago Press.

Wright, E. O. (1979). Class structure and income determination. New York: Academic Press.

Garry L. Rolison is Assistant Professor of Sociology at the University of Oklahoma and Research Fellow in the university's Center for Research on Education. 